\title{
Structural Changes in Wood Pulp Treated by 55 wt\% Aqueous Calcium Thiocyanate Solution
}

\author{
Makiko Hattori, Yoshihiko Shimaya, and Masatoshi SaIto \\ Central Laboratory, Asahi Chemical Industry Co., Ltd., \\ 11-7 Hacchonawate, Takatsuki, Osaka 569, Japan
}

(Received June 16, 1997)

\begin{abstract}
Attempt was made to clarify the structural change of wood pulp during the treatment of concentrated aqueous $(\mathrm{aq})$ calcium thiocyanate $\left(\mathrm{aq} \mathrm{Ca}(\mathrm{SCN})_{2}\right)$ solution at room temperature. For this purpose, X-ray, DSC, and CP/MAS ${ }^{13} \mathrm{C}$ NMR were used to measure changes of crystalline structure and formation of cellulose-solvent complex. X-Ray data indicated that $55 \mathrm{wt} \%$ aq $\mathrm{Ca}(\mathrm{SCN})_{2}$ soln. causes intracrystalline interplanar swelling of the wood pulp, forming cellulose-calcium thiocyanate addition compound. The interplanar spacing of $(1 \overline{1} 0),(110)$, and (200) planes increased for the former two planes and slightly decreased for the last one for treatment time $t_{\mathrm{d}}$ of $90 \mathrm{~min}$. From DSC thermograms of cellulose-55 wt $\%$ aq $\mathrm{Ca}(\mathrm{SCN})_{2}$ soln. mixture, exothermic heat $\Delta H$ for the formation of the addition compound was estimated to be $c a$. $11 \mathrm{kcal}$ $\mathrm{mol}^{-1}$, which was far lower than that for generation of cellulose sodium salt. The cellulose recovered from the system has quite different crystalline structure depending on treatment time and the reagents used for recovery. Up to $t_{\mathrm{d}}=90 \mathrm{~min}$, water recoverd the mixture of natural cellulose crystal (Cell-I) and hydrated cellulose (Cell-II), while the methanol and acetone recovered only Cell-I. After one day the structure of the recovered cellulose from the system was: water, Cell-II; methanol, Cell-I; acetone, almost amorphous cellulose.

KEY WORDS Cellulose / Calcium Thiocyanate Solution / Swelling / Crystal Structure Change / Cellulose Swelling Complex / Crystal Form /
\end{abstract}

Much investigation on the structural change of natural cellulose during swelling and dissolving into the solvents has been made hitherto for various systems. Aqueous (aq) sodium hydroxide solution as swelling reagent forms a swelling complex, soda-cellulose with different crystalline polymorph depending on $\mathrm{NaOH}$ concentration and temperature. ${ }^{1}$ In this case, the interplanar spacing of (110) and (200) crystal planes is almost invariable during the swelling, but only that of (110) plane is extended, leading to remarkable swelling of the cellulose. ${ }^{1}$ Kamide et $a l^{2,3}$ studied the structural changes of steam exploded pulp, in which intramolecular hydrogen bonds were partially destroyed, by aq $\mathrm{NaOH}$ and found that $7-10 \mathrm{wt} \%$ aq $\mathrm{NaOH}$ solution is able to dissolve steam exploded cellulose pulp near $4^{\circ} \mathrm{C}$. They reported that sodium and hydroxyl ions, which are accompanid by $c a$. four moles of water molecules per one mol of ion in the aqueous solution, penetrate the amorphous part and extend the spacing of (200) plane in the crystal region, resulting in dissolution without remarkable swelling of cellulose. In this case, cellulose has been proved not to form any alcoholate, different from the case of swelling by the concentrated aq $\mathrm{NaOH}$ soln. In ammonia/ammonium thiocyanate mixture, ${ }^{4}$ cellulose crystals convert from cellulose crystal form I (Cell-I) to Cell-II and Cell-III, and finally to amorphous. Then primary alcohol groups at $\mathrm{C}(6)$ position of glucopyranose change conformation from trans-gauche to gauche-trans, and gauche-gauche. In this manner the change of crystal structure reported in the literatures is quite dependent on swelling agent, solvent, and swelling and dissolving conditions.

Concentrated aq calcium thiocyanate solution is a swelling agent and solvent of some natural and regenerated cellulose ${ }^{5-8}$ and was once industrially used mainly for processing cotton fiber and paper. The degree of volumetric swelling of wood pulp in this solvent is far less than that in aq sodium hydroxide, but the crystal form of wood pulp changes into hydrate cellulose (CellII) after recovery using water as is the many cases of other swelling reagents. However, studies on the structure of cellulose by the treatment of calcium thiocyanate are very few ${ }^{9}$ and the change in crystalline structure during swelling and dissolution has never been disclosed. This paper studies change of solid structure of wood pulp in $55 \mathrm{wt} \%$ aq calcium thiocyanate solution at room temperature and effects of recovery reagents on crystalline structure.

\section{EXPERIMENTAL}

\section{Preparation of $55 \mathrm{wt} \%$ aq $\mathrm{Ca}(\mathrm{SCN})_{2}$ Solution}

$2.4 \mathrm{~kg}$ of calcium thiocyanate tetrahydrate (Wako Pure Chemical Ind. Ltd., Osaka) were dissolved in $400 \mathrm{~g}$ of ion-exchange water. The solution was centrifuged at $5 \times 10^{4} \mathrm{G}$ for $1 \mathrm{~h}$ at $45^{\circ} \mathrm{C}$ in a Hitachi model CR20B2 automatic high speed refrigerated centrifuge. The supernatant phase carefully sucked up was filtered by sintered-glass filter grade G4. The filtered solution was diluted by ion-exchange water to give $55 \mathrm{wt} \%$ aq $\mathrm{Ca}(\mathrm{SCN})_{2}$ soln. The concentration of $\mathrm{Ca}(\mathrm{SCN})_{2}$ in water was determined by precipitation titration using aq silver nitrate and aq KSCN soln. as titrants and aq ammonium iron(III) sulfate soln. as indicator.

\section{Treatment of Pulp by $55 \mathrm{wt} \%$ aq $\mathrm{Ca}(\mathrm{SCN})_{2}$ Solution and Regeneration from the Cellulose Solution}

The conifer pulp with viscosity-average degree of polymerization $D P_{\mathrm{v}}=968$ (prepared by sulfite pulping method, Alaska Pulp Co., U.S.A.) was used in this study. The pulp dipped in excess $55 \mathrm{wt} \%$ aq $\mathrm{Ca}(\mathrm{SCN})_{2}$ soln. at $25^{\circ} \mathrm{C}$ for 5-1440 min (treatment time was defined as $t_{\mathrm{d}}$ ) was recovered by ion exchange water (sample code H5-H1440), methanol (M5-M1440), and acetone 
(A5-A1440), respectively. Here the number in the sample code denotes $t_{\mathrm{d}}$ in minutes.

The conifer pulp was dipped in $55 \mathrm{wt} \%$ aq $\mathrm{Ca}(\mathrm{SCN})_{2}$ soln. at $25^{\circ} \mathrm{C}$ for 1 day and dissolved with agitation for $1 \mathrm{~h}$ at $120^{\circ} \mathrm{C}$, giving a $4 \mathrm{wt} \%$ cellulose solution. Cellulose was recovered from the solution by the addition of a large amount of acetone as a precipitant and was washed by acetone, followed by drying. The sample obtained (referred to as AS) was used as a perfectly amorphous cellulose sample when crystallinity was evaluated from the X-ray diffraction data.

\section{Polarization Microscopic Observation}

The morphological change of fibrous conifer pulp dipped in $55 \mathrm{wt} \%$ aq $\mathrm{Ca}(\mathrm{SCN})_{2}$ soln. on heating was observed using polarization microscope type Optiphot2POL (Nikon) equipped with heating plate type AFX-DX, and camera, FX-35DX (Nikon). The heating rate was $2{ }^{\circ} \mathrm{Cmin}^{-1}$.

\section{Wide Angle X-ray Diffractometry (WAX)}

WAX measurements on the dry cellulose samples were carried out on an X-ray diffractogram RU-300 (Rigaku) under the following conditions: Incident beam, $\mathrm{Cu}-K_{\alpha}$ with wave length of $0.154 \mathrm{~nm}$; accelerating voltage, $45 \mathrm{kV}$; beam current, $300 \mathrm{~mA}$; temperature, $25^{\circ} \mathrm{C}$. Crystallinity $\chi_{c}$ was estimated by a peak separation program (RINT2000 system, Rigaku) using sample AS as amorphous cellulose.

In order to measure WAX of the pulp dipped in $55 \mathrm{wt} \%$ aq $\mathrm{Ca}(\mathrm{SCN})_{2}$ soln. at $25^{\circ} \mathrm{C}$, conifer pulp was put in a glass capillary and solvent was added to the capillary containing cellulose. WAX measurement was immediately started after the addition of the solvent. A Mo- $K_{\alpha}$ ray was used as an incident beam, so as to minimize the absorption of X-ray by the solvent, at accelerating voltage $=58 \mathrm{kV}$ and beam current $=300 \mathrm{~mA}$. The diffraction intensity from the treated pulp was estimated by subtracting the diffraction of the solvent, glass capillary, and air.

\section{Differential Scanning Calorimetry (DSC)}

About $5 \mathrm{mg}$ of cellulose samples and $20 \mathrm{mg}$ of $55 \mathrm{wt} \%$ aq $\mathrm{Ca}(\mathrm{SCN})_{2}$ soln. were loaded in a stainless seal cell and stood still for $t_{\mathrm{d}}=0-60 \mathrm{~min}$ at $25^{\circ} \mathrm{C}$. The DSC thermograms were recorded on DSC type 200 (Seiko Electronic, Tokyo) at a heating rate of $3^{\circ} \mathrm{C} \mathrm{min}^{-1}$ from $5^{\circ} \mathrm{C}$ to $155^{\circ} \mathrm{C}$ under nitrogen gas flow of $100 \mathrm{ml} \mathrm{min}^{-1}$.

\section{$C P / M A S{ }^{13} C N M R$}

The ${ }^{13} \mathrm{C}$ NMR chemical shifts of conifer pulp, sample H1440, M1440 and A1440 were recorded on a JEOL FX200 NMR spectrometer and measured relative to external adamantane (upfield peak, $\delta=29.5 \mathrm{ppm}$ ). Enhancement of signals from the samples was achieved with cross polarization and magic angle spinning (CP/MAS) under the following conditions: Flip angle, $90^{\circ}$; width, $5.5 \mu \mathrm{s}$; repetition, $5 \mathrm{~s}$; cross-polarization contact time, 1-2 ms; data points, 8192 ; number of scanning, 512 times.

\section{RESULTS AND DISCUSSION}

\section{Structural Changes in Wood Pulp Dipped in aq Calcium} Thiocyanate Solution

Figure 1 shows polarization microscopic photographs of fibrous conifer pulp dipped in $55 \mathrm{wt} \%$ aq $\mathrm{Ca}(\mathrm{SCN})_{2}$ soln. on heating. The fibrils of conifer pulp show bright images up to $80^{\circ} \mathrm{C}$, thus not yet dissolved in the solvent, but above $80^{\circ} \mathrm{C}$, soluble and dissolved almost perfectly at $95^{\circ} \mathrm{C}$. Below $80^{\circ} \mathrm{C}$, the remarkable swelling was not observed, as reported by Karnik et al. ${ }^{10}$ and Bartunek ${ }^{11}$ on linter sheets of Sakillaridis cotton yarn at room temperature.

Figure 2 depicts equatorial WAX diffractograms of the pulp during dipping in $55 \mathrm{wt} \%$ aq $\mathrm{Ca}(\mathrm{SCN})_{2}$ soln. at $25^{\circ} \mathrm{C}$ for $t_{\mathrm{d}}$ from $0-12 \mathrm{~min}$ (represented by $t_{\mathrm{d}}=0 \mathrm{~min}$ ) to $1440-1452\left(t_{\mathrm{d}}=1440 \mathrm{~min}\right)$. Diffraction intensity of pulp is plotted against diffraction angel $2 \theta$ for the $\mathrm{Cu}-K_{\alpha}$ ray transformed from that of the Mo- $K_{\alpha}$ ray. The height of peaks due to $(1 \overline{1} 0)$ plane $\left(2 \theta=14.7^{\circ}\right),(110)\left(16.4^{\circ}\right)$, and (200) $\left(22.4^{\circ}\right)$ of Cell-I monotonically decreases in intensity with an increase of $t_{\mathrm{d}}$ and the former two peaks seem to disappear at $t_{\mathrm{d}}=90 \mathrm{~min}$. The peak position of (200) plane slightly shifts from $2 \theta=22.4^{\circ}$ to around $23^{\circ}$ with increase in $t_{\mathrm{d}}$. In the figure diffractograms at $t_{\mathrm{d}}=$ $90 \mathrm{~min}$ and $1440 \mathrm{~min}$ almost overlap, indicating that crystalline structure did not change from $90 \mathrm{~min}$ to at least 1 day at room temperature. Instead of the decrease of the peak intensity of Cell-I, a new peak with large half value width appears near $10.5^{\circ}$ at $t_{\mathrm{d}}$ more than $12 \mathrm{~min}$, increasing in intensity up to $t_{\mathrm{d}}=90 \mathrm{~min}$. The interplanar spacing corresponding to the peak top is $0.84 \mathrm{~nm}$. The remarkable expansion of some cellulose crystalline plane occurs by swelling agents, such as amines, ${ }^{12}$ aq $\mathrm{ZnCl}_{2}$ soln., ${ }^{13}$ aq LiSCN soln. ${ }^{14}$ as well as aq sodium hydroxide soln., as a result of formation of cellulose swelling complexes. The (110) interplanar spacing of Cell-I is said to increase from $0.61 \mathrm{~nm}$, in native cellulose, to $0.88-1.63 \mathrm{~nm}$, as exemplified by amines and sodium hydroxide cellulose compound. ${ }^{15}$ Therefore the broad peak at $2 \theta=10.5^{\circ}$ might arise from the diffraction of expanded (110) plane including (110) plane of the cellulose swelling complex formed between cellulose and calcium thiocyanate accompanied by some moles of water molecules. We investigated the interaction between cellulose and $55 \mathrm{wt} \%$ aq calcium thiocyanate soln. using IR and NMR, finding that calcium thiocyanate molecules hydrated by less than 4 mol of water form 5-membered cyclic structure with two oxygen atoms of primary alcohol at $\mathrm{C}(6)$ position $(\mathrm{O}(6))$ and in a glucopyranose ring $(\mathrm{O}(5))$ in glucose. ${ }^{16}$ This situation might influence increase in interplanar spacing of (110) and (110) planes by destroying the intramolecular hydrogen bond, such as $\mathrm{C}(3) \mathrm{O}-\mathrm{H} \cdots \mathrm{O}\left(5^{\prime}\right)$, as well as intermolecular hydrogen bond $\mathrm{C}(2) \mathrm{OH} \cdots \mathrm{O}\left(6^{\prime}\right)$ and $\mathrm{C}(6) \mathrm{O}$ $\mathrm{H} \cdots \mathrm{O}\left(2^{\prime}\right)$ in the natural cellulose crystal. The increase in spacings of the both planes may bring about slight decrease in the spacing of the (200) plane, as illustrated in Figure 3.

Figure 4 shows DSC thermograms of the pulp in $55 \mathrm{wt} \%$ aq $\mathrm{Ca}(\mathrm{SCN})_{2}$ soln. at various $t_{\mathrm{d}}$. Every thermogram below $t_{\mathrm{d}}=60 \mathrm{~min}$ indicates an exothermic peak near $40^{\circ} \mathrm{C}$. Note that the peak temperature is far 
a)

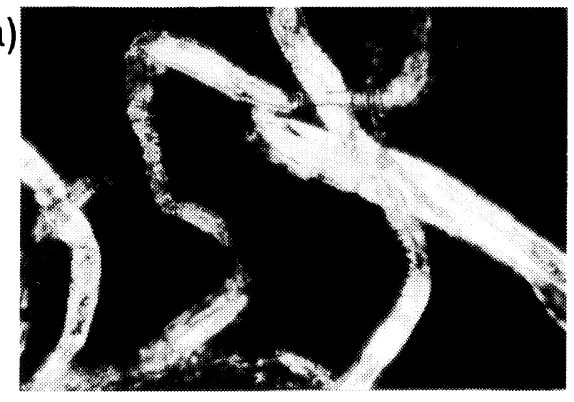

b)



c)

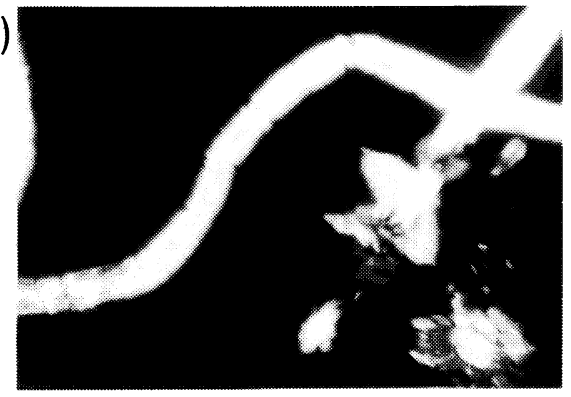

d)

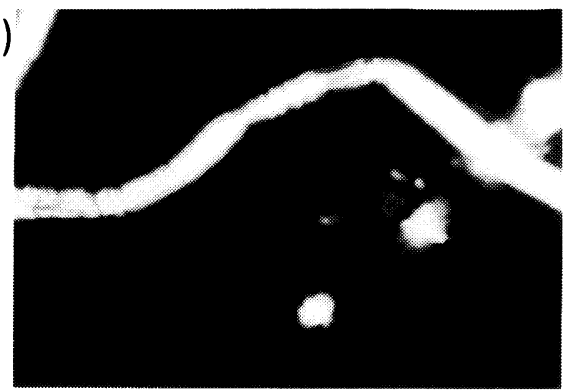

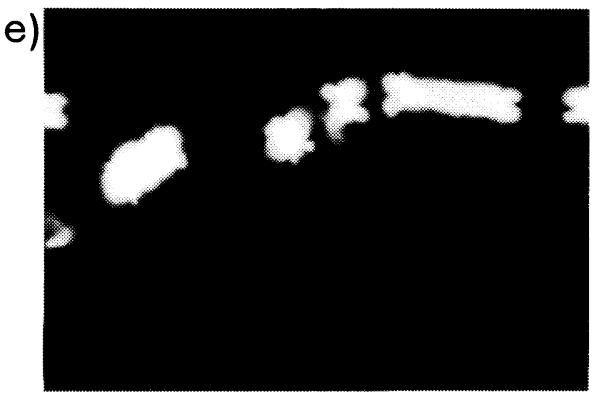
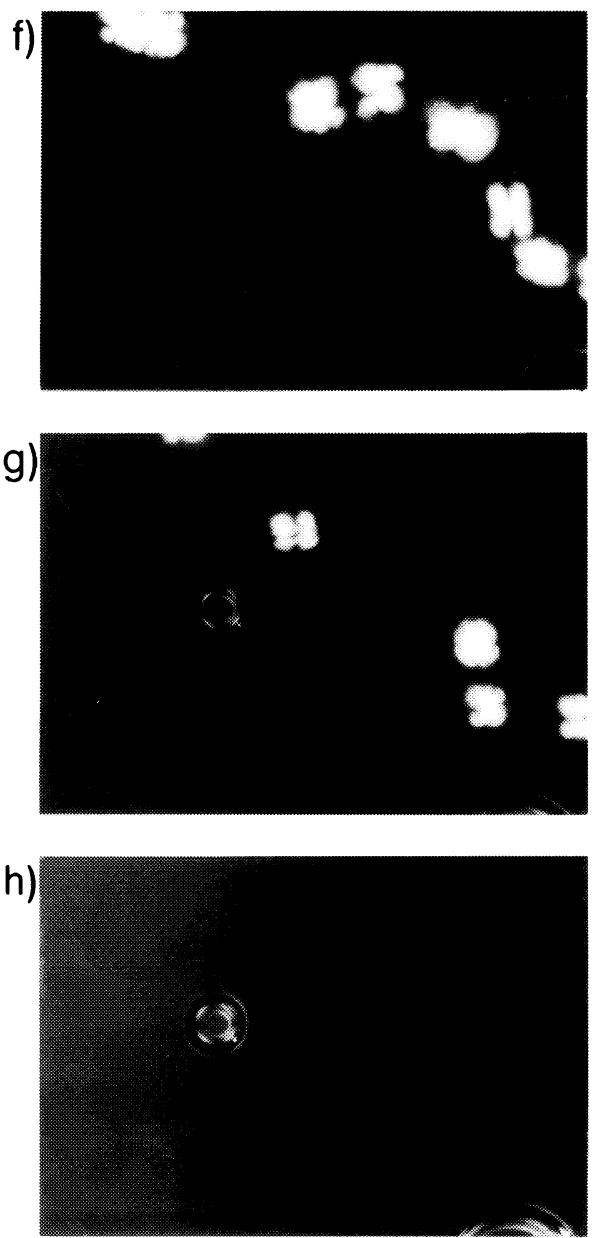

Figure 1. Dissoluting of conifer pulp in $55 \mathrm{wt} \%$ aq calcium thiocyanate solution on heating observed by polarization microscope. Temperature: a) $17.5^{\circ} \mathrm{C}$; b) $70^{\circ} \mathrm{C}$; c) $81.6^{\circ} \mathrm{C}$; d) $84^{\circ} \mathrm{C}$; e) $88^{\circ} \mathrm{C}$; f) $90.4^{\circ} \mathrm{C}$; g) $94.9^{\circ} \mathrm{C}$; h) $95.8^{\circ} \mathrm{C}$.

lower than the dissolving temperature (about $95^{\circ} \mathrm{C}$ ) of the pulp, as shown in Figure 1. Interestingly the amount of exotherm $\Delta H$ estimated from the peak area was almost zero at $t_{\mathrm{d}}=60 \mathrm{~min}$, beyond which Cell-I crystal disappeared and the new peak becomes remarkable near $2 \theta=10.5^{\circ}$ in X-ray diffraction (Figure 2). This exothermic behavior of cellulose is probably evidence of the formation of specific compounds. Contrary to this, we confirmed that no peak was observed near the dissolving temperature $\left(c a .95^{\circ} \mathrm{C}\right)$. This might mean that the addition compound formed in the cellulose easily dissolves in $55 \mathrm{wt} \%$ aq $\mathrm{Ca}(\mathrm{SCN})_{2}$ soln. only by virtue of thermal Brownian motion of cellulose chains. Considering the results on X-ray diffraction, it is implied that hydrated calcium thiocyanate molecules break down intermolecular hydrogen bonds in cellulose solid at room temperature and expand the Cell-I crystalline lattice, especially interplanar spaces of (110) and (110) planes, forming specific compounds with cellulose. This reaction was almost complete for about $1.5 \mathrm{~h}$ after dipping, when the sufficient amount of $55 \%$ aq calcium thioyanate exists.

Crystallinity $\chi_{\mathrm{c}}$ dependence of $\Delta H$ for the pulp- and the samples $\mathrm{H} 10-\mathrm{H} 1440$ in $55 \mathrm{wt} \%$ aq $\mathrm{Ca}(\mathrm{SCN})_{2}$ soln. at $t_{\mathrm{d}}=0$ is illustrated in Figure 5. Here the samples $\mathrm{H} 10-\mathrm{H} 1440$ include crystal form Cell-I and Cell-II as described later. Obviously, all data fall on one line $\left[\Delta H=-3.06\left(1-\chi_{\mathrm{c}}\right)-1.02\left(\mathrm{kcal} \mathrm{mol}^{-1}\right)\right.$, where the sign of endothermic heat was taken as positive], irrespective of crystal form of the samples. From the equation, it is expected that $\Delta H$ for the hypothetically perfect crystal and amorphous cellulose in aq calcium thiocyanate is -1.02 and $-4.08 \mathrm{kcal} \mathrm{mol}^{-1}$, respectively. $\Delta H$ observed here might be a product from contributions of exothermic 


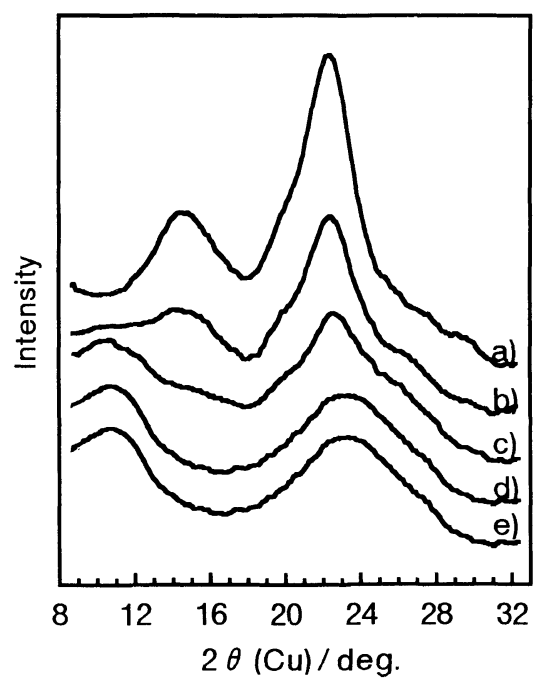

Figure 2. Change in X-ray diffractogram of conifer pulp during treatment in $55 \mathrm{wt} \%$ aq calcium thiocyanate soln. at $25^{\circ} \mathrm{C}$. Treatment times: a) $0-12 \mathrm{~min}$; b) $12-24 \mathrm{~min}$; c) $66-78 \mathrm{~min}$; d) $90-102 \mathrm{~min}$; e) $1440-1452 \mathrm{~min}$.
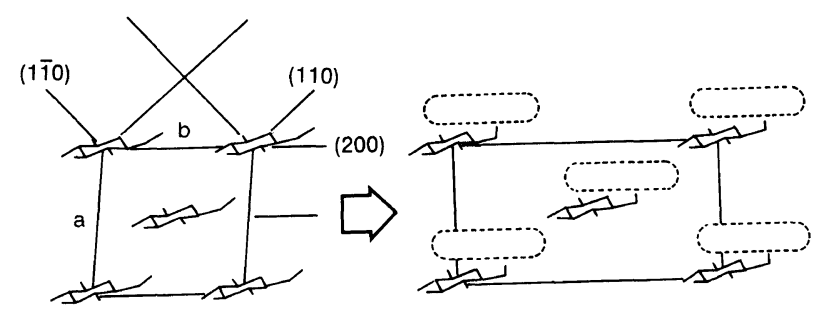

Figure 3. Structural changes in natural cellulose treated by $55 \mathrm{wt} \%$ aq calcium thiocyanate solution.



Figure 4. DSC curves of conifer pulp in $55 \mathrm{wt} \%$ aq calcium thiocyanate soln. on heating. Treatment times $t_{\mathrm{d}}$ : a) $0 \mathrm{~min}$; b) $10 \mathrm{~min}$; c) $15 \mathrm{~min}$; d) $20 \mathrm{~min}$; e) $30 \mathrm{~min}$; f) $40 \mathrm{~min}$; g) $60 \mathrm{~min}$.

complex formation and endothermic hydrogen bond breaking. If we assume that aq $\mathrm{Ca}(\mathrm{SCN})_{2}$ breaks two hydrogen bonds [one interplanar hydrogen bond, one $\mathrm{O}(3)-\mathrm{O}\left(5^{\prime}\right)$ intramolecular hydrogen bond; (ca. $5 \mathrm{kcal}$ $\left.\mathrm{mol}^{-1}\right)^{17}$ ] per grucopyranose unit with $\chi_{\mathrm{c}}=100 \%$ and at the same time forms a complex with a glucopyranose unit, the assumed $\Delta H$ due to complex formation is roughly estimated as $-11 \mathrm{kcal} \mathrm{mol}^{-1}$. This $\Delta H$ value is far lower than the exothermic heat for generation of cellulose sodium salt or alcoholate $(-25-30 \mathrm{kcal}$ $\left.\mathrm{mol}^{-1}\right) .^{18}$

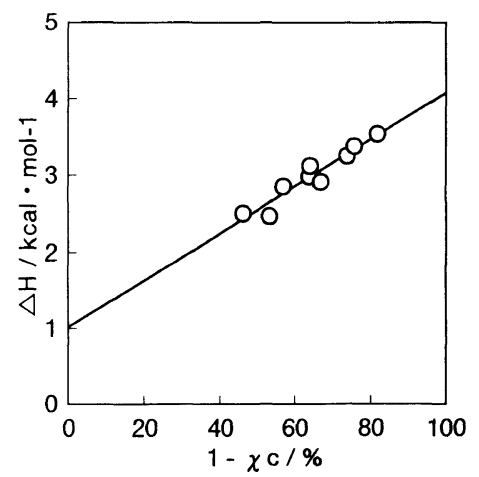

Figure 5. Relationship between exotherm $\Delta H$ and amorphous content $\left(1-\chi_{c}\right)$ for pulp and samples H10-H1440 in $55 \mathrm{wt} \%$ aq calcium thiocyanate soln.

Structure of Cellulose Regenerated by Various Reagents after Treatment in aq Calcium Thiocyanate Solution

The changes of X-ray diffractograms of the samples H5- 1440 recovered by water, M5-1440 by methanol, and A5-1440 by acetone are depicted in Figures $6 \mathrm{a}, \mathrm{b}$, and c, respectively. In every case, the recovered cellulose samples retain Cell-I crystal form up to $t_{\mathrm{d}}=60 \mathrm{~min}$, although the crystallinity was far lower than that of untreated pulp. The peak at $2 \theta=10.5^{\circ}$ observed in Figure 2 almost perfectly disappeared for all recovered samples. In the case of water, however, a very weak peak at $2 \theta=11.8^{\circ}$ and shoulder at $2 \theta=21.8^{\circ}$ as well as the peak due to Cell-I were observed at $t_{\mathrm{d}}=30$ and $60 \mathrm{~min}$ (indicated by arrows on the diffractogram) and seem to increase in intensity with $t_{\mathrm{d}}$. Instead, the peak intensity of Cell-I monotonically decreases with $t_{\mathrm{d}}$, disappearing around $t_{\mathrm{d}}=90 \mathrm{~min}$. The peaks at $2 \theta=11.8$, 20.2, and $21,8^{\circ}$ assigned to Cell-II become remarkable after $t_{\mathrm{d}}=90 \mathrm{~min}$, although these peaks were never observed for cellulose dipped in $55 \%$ aq calcium thiocyanate soln. These results indicate that up to $t_{\mathrm{d}}=90 \mathrm{~min}$ Cell-I which probably remains undestroyed by the $55 \mathrm{wt} \%$ aq calcium thiocyanate is recovered and Cell-II crystal is formed from cellulose-calcium thiocyanate complex by water recovery. By methanol and acetone as recovery reagents, Cell-I was recovered even in the $t_{\mathrm{d}}$ range more than $90 \mathrm{~min}$, where the peaks of Cell-I were not detected in Figure 2. At $t_{\mathrm{d}}=1440 \mathrm{~min}$ ( 1 day), the structure of the cellulose is quite different depending on the reagents used: Water recovers only Cell-II, methanol recovers only Cell-I and acetone gives the cellulose with very few crystal component.

Figures $7 \mathrm{a}-\mathrm{c}$ show the treatment time dependence of $\chi_{\mathrm{c}}$ estimated by applying peak separation method to the diffractograms in Figure 6 . In the figure, $\chi_{c}$ of the Cell-I (unfilled circle) and Cell-II (filled circle) are indicated separately for the samples regenerated by water, although the accuracy of $\chi_{\mathrm{c}}$ for Cell-II up to $t_{\mathrm{d}}=60 \mathrm{~min}$ is not always enough due to low diffraction intensity. For every sample the $\chi_{\mathrm{c}}$ of Cell-I decreases up to $60 \mathrm{~min}$, which just corresponds to the decay of Cell-I crystals and formation of a new crystalline structure of the calcium thiocyanate addition compound, as shown in Figure 2. In water, $\chi_{\mathrm{c}}$ of Cell-I becomes zero at $90 \mathrm{~min}$ and the crystallinity of Cell-II increases up to that time. After $90 \mathrm{~min}$, only the cellulose samples with Cell-II crystal having constant $\chi_{\mathrm{c}}$ $(=18 \%)$ were recovered by water. As mentioned before, 




Figure 6. X-Ray diffractograms of conifer pulp treated with $55 \mathrm{wt} \%$ aq calcium thiocyanate soln. for treatment time $t_{\mathrm{d}}$ and recovered by water (A), methanol (B), and acetone (C). a) untreated conifer pulp; b) $t_{\mathrm{d}}=30 \mathrm{~min}$; c) $60 \mathrm{~min}$; d) $90 \mathrm{~min}$; e) $150 \mathrm{~min}$; f) $1440 \mathrm{~min}$.

methanol recovers only Cell-I and $\chi_{\mathrm{c}}$ is almost constant around $40 \%$ from $t_{\mathrm{d}}=60$ to $1440 \mathrm{~min}$. $\chi_{\mathrm{c}}$ of cellulose recovered by acetone gradually decreases after $60 \mathrm{~min}$, becoming zero at $t_{\mathrm{d}}=1440 \mathrm{~min}$. Concerning the structure of the cellulose recovered from ramie in $21 \%$ aq $\mathrm{NaOH}$ soln. with water at $20-200^{\circ} \mathrm{C}$ after the complete formation of Na-Cell- $\mathrm{I}_{\mathrm{I}}$, Hayashi et al. reported that a mixture of Cell-I and Cell-II was recovered from the system and cellulose with the higher proportion of CellI was recovered with increase in temperature of water. ${ }^{19-21}$ According to them, this is because the water cellulose, which gives Cell-II on drying, is not formed at higher temperature. Taking into account the results

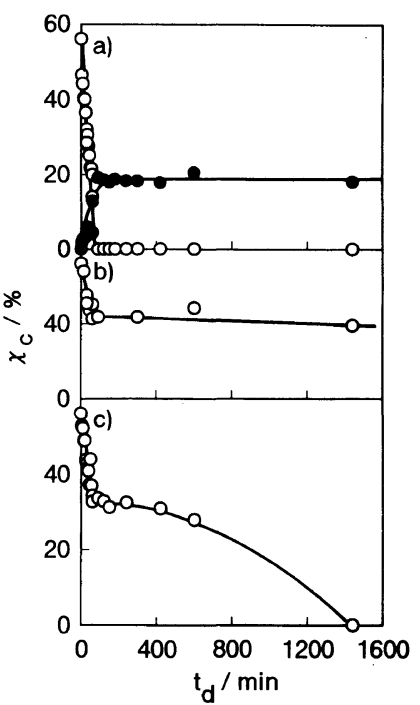

Figure 7. Treatment time $t_{\mathrm{d}}$ dependence of crystallinity $\chi_{\mathrm{c}}$ of conifer pulp recovered by water (a), methanol (b), and acetone (c). $\bigcirc$, Cell-I crystal; $\bullet$, Cell-II crystal.

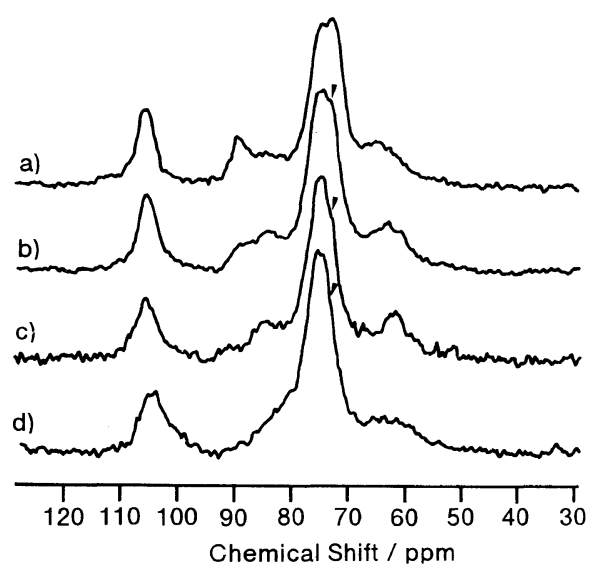

Figure 8. $\mathrm{CP} / \mathrm{MAS}{ }^{13} \mathrm{C}$ NMR spectra of conifer pulp, untreated (a) and treated for $1440 \mathrm{~min}$ followed by recovery using methanol (b), water (c), and acetone (d).

of Hayashi et al., crystalline of aq calcium thiocyanatecellulose addition compound is considered to be recovered to Cell-II through the water cellulose. Based on this assumption, methanol and acetone, never reported to form any definite addition compounds with cellulose, might not hydrate with cellulose, resulting in only the decomposition of the aq thiocyanate addition compounds and reformation of Cell-I crystal. The only difference between methanol and acetone is the content of Cell-I for a long treatment time.

The CP/MAS ${ }^{13} \mathrm{C}$ NMR spectra of the samples at $t_{\mathrm{d}}=1440 \mathrm{~min}$ and untreated pulp as a reference are illustrated in Figure 8. The peaks in the spectrum are assigned to as follows: $\mathrm{C}(1)$, around $105 \mathrm{ppm}$; $\mathrm{C}(4)$, from 89 to $80 \mathrm{ppm} ; \mathrm{C}(2), \mathrm{C}(3)$, and $\mathrm{C}(5), 80-70 \mathrm{ppm}$; $\mathrm{C}(6), 67-60 \mathrm{ppm}$. In the case of the recovered celluloses the peak at $89 \mathrm{ppm}$ due to $\mathrm{C}(4)$ carbon is lower in intensity than that of the untreated cellulose and as an extreme case, no peak was observed by acetone. Instead, the ratio of peak areas at $84 \mathrm{ppm}$ to $89 \mathrm{ppm}$, referred to as $\chi_{\mathrm{am}}(\mathrm{C} 3)$, increased in the order of acetone, water, and methanol. Concerning $\mathrm{C}(2), \mathrm{C}(3)$, and $\mathrm{C}(6)$ carbon peaks, the peak intensity at $73 \mathrm{ppm}$, clearly highest for the un- 
treated cellulose, becomes rather obscure in the order of methanol, water and acetone, as indicated by arrows. Kamide et $a .^{22}$ indicated that $\chi_{\mathrm{am}}(\mathrm{C} 3)$ is a measure of the degree of break down of intramolecular hydrogen bonds between $\mathrm{C}(3)-\mathrm{OH} \cdots \mathrm{O}\left(5^{\prime}\right)$ and the peak at 73 ppm is due to $\mathrm{C}(3)$ and $\mathrm{C}(2)$ carbon when the intermolecular hydrogen bonds, such as $\mathrm{C}(2) \mathrm{O}-\mathrm{H} \cdots \mathrm{O}\left(6^{\prime}\right)$ for the natural cellulose and $\mathrm{C}(6) \mathrm{OH} \cdots \mathrm{O}\left(2^{\prime}\right)$ for regenerated cellulose were formed, respectively. From these facts, the intra- and intermolecular hydrogen bonds in the recovered cellulose at $t_{\mathrm{d}}=1440 \mathrm{~min}$ are expected to develop in the order of methanol, water, and acetone. The cellulose- $55 \%$ aq calcium thiocyanate soln. forms a gel when the cellulose solution is immersed in ketones, such as acetone and methylethylketone, and alcohols such as methanol at room temperature. We measured the content of calcium thiocyanate and acetone or methanol in the cellulose gel formed, finding that acetone does not penetrate the system and only extracts calcium thiocyanate and water, while methanol immediately enters the system, extracting calcium thiocyanate and water. ${ }^{23}$ These findings imply that methanol destroys the calcium thiocyanate cellulose addition compounds just when the swollen cellulose is immersed in the methanol media. Acetone might gradually decompose the addition compound, restricting the reformation of intra- and inter molecular hydrogen bondings of cellulose, which may lead to lowering the crystallinity of Cell-I comparing with methanol.

\section{CONCLUSIONS}

Regarding the structure of cellulose dipped in $55 \mathrm{wt} \%$ aq $\mathrm{Ca}(\mathrm{SCN})_{2}$ soln. at room temperature, $55 \mathrm{wt} \%$ aq $\mathrm{Ca}(\mathrm{SCN})_{2}$ soln. brings about intracrystalline swelling of wood pulp, forming an addition compound between thiocyanate and cellulose molecules. The crystals of wood pulp (Cell-I) are destroyed for a treatment time $t_{\mathrm{d}}$ of $90 \mathrm{~min}$, forming a new structure with larger interplanar spacings of (110) and (110) planes and slightly smaller that of (200) plane than those of the original cellulose. The structure of the cellulose recovered from cellulose- $55 \mathrm{wt} \%$ aq $\mathrm{Ca}(\mathrm{SCN})_{2}$ soln. using water, methanol and acetone as recovery agents differs depending on the treatment time and reagent. Up to $t_{\mathrm{d}}=60 \mathrm{~min}$, the Cell-I remaining undestroyed was recovered irrespective of the reagents. At $t_{\mathrm{d}}=90 \mathrm{~min}$, water recovers the hydrated cellulose (Cell-II) and methanol and acetone gave only Cell-I. This is possibly because the cellulose forms a hydrated compound with water and does not interact with methanol and acetone. The final structure of the recovered cellulose by the three reagents was as follows: Water, Cell-II; methanol, Cell-I; acetone, almost amorphous.

Acknowledgment. Authors would express their thanks to Dr. K. Okajima, Director of Asahi Chemical Industry Co., Ltd. for valuable discussion.

\section{REFERENCES}

1. See for example, W. A. Sisson, in "Cellulose and Cellulose Derivatives," E. Otto, Ed., Interscience Publishers, Inc., New York, N.Y., 1946, Chapter III, Section A, p 266; J. A. Howsmon and W. A. Sisson, in "Cellulose and Cellulose Derivatives," Part I, E. Otto, H. M. Spurlin, and M. W. Grafflin, Ed., Interscience Publishers, Inc., New York, N.Y., 1954, Chapter IV, Section B, p 316; M. Fujii, in "Cellulose Handbook," H. Sobue and N. Migita, Ed., Asakura, Tokyo, 1958, Chapter 9, p 268.

2. K. Kamide, K. Okajima, and K. Kowsaka, Polym. J., 24, 71 (1992).

3. K. Kamide, K. Yasuda, T. Matsui, K. Okajima, and T. Yamashiki, Cellulose Chemistry and Technology, 24, 23 (1990).

4. J. A. Cuculo, C. B. Smith, U. Sangwatanaroj, E. O. Stejskal, and S. S. Sankar, J. Polym. Sci., Polym. Chem., 32, 229 (1994); J. A. Cuculo, C. B. Smith, U. Sangwatanaroj, E. O. Stejskal, and S. S. Sankar, J. Polym. Sci., Polym. Chem., 32, 241 (1994).

5. J. O. Warwicker, in "Cellulose and Cellulose Derivatives," Part IV, N. M. Bikales and L. Segal, Ed., Wiley-Interscience, New York, N.Y., 1971, Chapter XIII, Section H, p 348.

6. H. E. Williams, J. Soc. Chem. Ind., 40, $221 \mathrm{~T}$ (1921).

7. H. Erbring and H. Geinitz, Kolloid-Z, 84, 25 (1938).

8. O. A. Wuorinen and A. Visapää, Paperi puu, 41, 345 (1959).

9. J. O. Warwicker, R. Jeffries, R. L. Colbaran, and R.N. Robinson, Shirley Institute Pamphlet, No. 93, 170 (1966).

10. M. G. Karnik and S. C. Devadatta, J. Univ. Bombay, 17A, 49 (1948).

11. R. Bartunek, Papier, 7, 153 (1953).

12. J. O. Warwicker, in "Cellulose and Cellulose Derivatives," Part IV, N. M. Bikales and L. Segal, Ed., Wiley-Interscience, New York, N.Y., 1971, Chapter XIII, Section H, p 349 and p 363.

13. G. Centola and F. Pancirolli, Ind. Carta (Milan), 1, 87 (1947).

14. J. Katz and J. C. Derksen, Rec. Trav. Chim., 50, 149 (1931).

15. J. A. Howsmon and W. A. Sisson, in "Cellulose and Cellulose Derivatives," Part I, E. Otto, H. M. Spurlin, and M. W. Grafflin, Ed., Interscience Publishers, Inc., New York, N.Y., 1954, Chapter IV, Section B, p 326; M. Fujii, in "Cellulose Handbook," $\mathrm{H}$. Sobue and N. Migita, Ed., Asakura, Tokyo, 1958, Chapter 9, p 274.

16. M. Hattori, T. Koga, Y. Shimaya, and M. Saito, Polym. J., 30, 43 (1998).

17. H. Sobue, in "Cellulose Handbook," H. Sobue and N. Migita, Ed., Asakura, Tokyo, 1958, Chapter 1, p 14.

18. M. Fujii, in "Cellulose Handbook," H. Sobue and N. Migita, Ed., Asakura, Tokyo, 1958, Chapter 9, p 276.

19. J. Hayashi, T. Yamada, K. Kimura, and S. Watanabe, Nippon Kagaku Kaishi, No. 10, 1964 (1974).

20. J. Hayashi, T. Yamda, and K. Kimura, Appl. Polym. Symp., 28, 713 (1976).

21. J. Hayashi, Cell. Commun., 2, 6 (1995).

22. K. Kamide, K. Okajima, K. Kowsaka, and T. Matsui, Polym. J., 17, 701 (1985).

23. M. Hattori, H. Shimaya, T. Koga, and M. Saito, unpublished results. 